\title{
Pengaruh model REACT berbantuan virtual laboratory terhadap pemahaman konsep pada materi dinamika rotasi dan kesetimbangan benda tegar
}

\author{
Puspita Yuma Sari \\ Pendidikan Fisika, Universitas Siliwangi, Indonesia \\ Surat-e: pyumasari@gmail.com \\ Nana \\ Pendidikan Fisika, Universitas Siliwangi, Indonesia \\ Surat-e: nana@unsil.ac.id
}

\begin{abstract}
Abstrak. Penelitian ini dilatar belakangi oleh Skor TIMSS bidang fisika Indonesia sangat rendah dan berada di bawah rata-rata internasional, hal tersebut disebabkan karena pembelajaran fisika di Indonesia kurang merangsang dan kurang dapat meningkatkan kemampuan tingkat tinggi.. Maka masalah pokok yang akan dicari pemecahannya melalui penelitian ini adalah perbedaan pemahaman konsep antara kelompok peserta didik yang belajar mengunakan model pembelajaran REACT berbantuan virtual laboratory, peserta didik yang belajar menggunakan model pembelajaran REACT dan model pembelajaran konvensional. Tujuan penulisan ini adalah mendeskripsikan pengaruh model REACT berbantuan virtual laboratory terhadap pemahaman konsep. Metode yang digunakan yaitu studi kepustakaan. Jadi, dapat disimpulkan model pembelajaran REACT dengan berbantuan virtual laboratory akan meningkatkan pemahaman konsep pada materi kesetimbangan benda tegar.
\end{abstract}

Kata kunci: REACT, Virtual laboratory

\begin{abstract}
This research is motivated by the TIMSS score in the Indonesian physics field which is very low and below the international average, this is because learning physics in Indonesia is less stimulating and less able to improve high-level skills. Then the main problem that will be solved through this research is the difference in concept understanding between groups of students who learn to use REACT learning models assisted by virtual laboratories, students who learn to use REACT learning models, and conventional learning models. The purpose of this paper is to describe the effect of a virtual laboratory-assisted REACT model on understanding concepts. The method used is a literature study. So, it can be concluded that the REACT learning model with the assistance of a virtual laboratory will increase the understanding of concepts in the equilibrium of rigid bodies.
\end{abstract}

Keywords: REACT, Virtual laboratory

\section{Pendahuluan}

Pendidikan merupakan topik yang sangat menarik untuk dibahas, karena pada dasarnya pendidikan merupakan suatu proses untuk memanusiakan manusia. Kemajuan suatu bangsa dapat diketahui dari kualitas pendidikannya. Bangsa yang maju memiliki kualitas pendidikan yang baik. Pendidikan menjadi tujuan dari bangsa Indonesia yang tertuang dalam pembukaan Undang-Undang Dasar 1945 alenia keempat. Pendidikan merupakan salah satu investasi penting bagi negara berkembang seperti Indonesia untuk kemajuan negara di masa mendatang karena menjadi salah satu upaya untuk meningkatkan kualitas sumber daya manusia. Perbaikan demi perbaikan telah dilakukan dalam dunia pendidikan untuk mendapatkan peningkatan kualitas pendidikan pendidikan di Indonesia agar dapat sejalan dengan perkembangan era globalisasi ini. 
Menurut Sistem Pendidikan Nasional Tahun 2003, pendidikan merupakan usaha sadar dan terencana untuk mewujudkan suasana belajar dan proses pembelajaran agar peserta didik secara aktif mengembangkan potensi dirinya untuk memiliki kekuatan spiritual, pengendalian diri, kepribadian, kecerdasan, akhlak mulia, serta keterampilan yang diperlukan dirinya, masyarakat, bangsa, dan negara. Pendidikan merupakan suatu proses pembelajaran yang bertujuan untuk mengembangkan kompetensi kognitif, afektif, dan psikomotorik peserta didik, baik melalui interaksi maupun pengalaman belajar peserta didik.

Belajar merupakan proses interaksi edukatif yang terikat pada tujuan, terarah pada tujuan, dan dilaksanakan khusus untuk mencapai tujuan [1]. Melalui proses belajar, yang diharapkan berhasil mencapai tujuan adalah peserta didik itu sendiri. Oleh karena itu, hal terpenting dalam interaksi belajar mengajar adalah peserta didik. Tujuan tersebut tercermin sebuah harapan dari proses pendidikan di Indonesia yang mengharapkan output dan outcome berkualitas dan memiliki daya saing tinggi kedepannya. Rendahnya kualitas output dan outcome peserta didik menunjukkan ketidakmampuan proses pendidikan untuk menghantarkan peserta didik kepada tujuan pendidikan yang telah dirancang.

Rendahnya kualitas pendidikan di Indonesia dapat terlihat dari data hasil studi internasional, diantaranya: Pertama, Indeks pembangunan pendidikan untuk semua atau education for all. Berdasarkan laporan Organisasi Pendidikan, Ilmu Pengetahuan, dan Kebudayaan PBB (UNESCO) tahun 2012, Indonesia berada di peringkat ke-64 dari 120 negara. Tahun lalu, Indonesia berada di peringkat ke-69 dari 127 negara [2].

Kedua, hasil PISA (Program for International Student Assesment) yang diselenggarakan pada tahun 2009, studi ini diselenggarakan pada tahun 2000, 2003, 2006, 2009 dan seterusnya. Posisi Indonesia dibandingkan negara-negara lain berdasarkan studi PISA (lihat Tabel 1).

Tabel 1. Posisi Indonesia dibandingkan Negara-negara Lain Berdasarkan studi PISA (Kemendikbud, 2011a)

\begin{tabular}{cccccc}
\hline Tahun Studi & $\begin{array}{c}\text { Mata } \\
\text { Pelajaran }\end{array}$ & $\begin{array}{c}\text { Skor Rata-rata } \\
\text { Indonesia }\end{array}$ & $\begin{array}{c}\text { Skor Rata-rata } \\
\text { Internasional }\end{array}$ & $\begin{array}{c}\text { Peringkat } \\
\text { Indonesia }\end{array}$ & $\begin{array}{c}\text { Jumlah } \\
\text { Negara } \\
\text { Peserta Studi }\end{array}$ \\
\hline \multirow{2}{*}{2000} & Membaca & 371 & 500 & 39 & 41 \\
& Matematika & 369 & 500 & 39 & 38 \\
2003 & Sains & 393 & 500 & 39 & 40 \\
& Membaca & 382 & 500 & 38 & 56 \\
& Matematika & 360 & 500 & 38 & 57 \\
& Sains & 395 & 500 & 48 & 50 \\
\end{tabular}

Tabel diatas menunjukkan bahwa rata-rata skor prestasi literasi membaca, matematika, dan sains peserta didik Indonesia berada signifikan dibawah rata-rata internasional. Penelitian Program for International Student Assesment (PISA) tahun 2009 prestasi literasi membaca peserta didik Indonesia berada pada peringkat ke-57 dari 65 negara, literasi matematika berada pada peringkat ke-61 dari 65 negara, dan literasi Sains berada pada peringkat ke-60 dari 65 negara. [3]

Ketiga, Berdasarkan jumlah skor yang dicapai baik pada TIMSS 2007 maupun TIMSS 2011, Indonesia mendapat predikat low science benchmark. Predikat tersebut menyatakan bahwa peserta didik Indonesia hanya mampu mengenal sebagian fakta-fakta dasar dari ilmu sains khususnya dalam mata pelajaran fisika [4].

Menurut Mundilarto Fisika merupakan ilmu yang berusaha memahami aturan-aturan alam yang dapat dideskripsikan secara matematis. Adanya mata pelajaran fisika di SMA dimaksudkan agar peserta didik mampu menguasai konsep-konsep fisika dan diharapkan dapat menumbuhkan kemampuan berpikir peserta didik yang berguna untuk memecahkan masalah yang ada dalam kehidupan sehari-hari [5]. Konsep fisika yang abstrak menimbulkan permasalahan dalam proses pembelajaran fisika di sekolah. Konsep tersebut sulit dipahami peserta didik, sehingga peserta didik cenderung pasif dalam pembelajaran fisika.

Dalam proses pembelajaran fisika, penguasaan konsep sangatlah penting. Anderson dan Krathwohl menyatakan bahwa dengan penguasaan konsep, peserta didik dapat meningkatkan kemahiran intelektualnya 
dan membantu dalam memecahkan persoalan yang dihadapinya serta menimbulkan pembelajaran bermakna [6]. Hal ini diperkuat oleh BSNP mengenai tujuan umum pembelajaran fisika yaitu agar peserta didik memiliki kemampuan untuk menguasai konsep dasar fisika, memiliki kemampuan untuk dapat mengembangkan pengetahuannya, memiliki keterampilan dan sikap yang dapat menjadi bekal bagi peserta didik untuk melanjutkan pendidikan pada jenjang yang lebih tinggi, serta mengembangkan ilmu dan teknologi.

Adanya beberapa perubahan dalam dunia pendidikan, dapat memberikan dampak yang besar dalam proses pembelajaran. Misalnya adalah kesiapan dan kemampuan guru untuk mengajar serta kemampuan guru untuk mendesain pembelajaran agar selalu menarik bagi peserta didik. Dampak tersebut mengharuskan guru untuk selalu meng-update informasi tentang bagaimana seharusnya mengajar serta media yang digunakan. Sehingga diharapkan peningkatan kualitas pendidikan menjadi lebih baik dari sebelumnya. Peningkatan kualitas pendidikan tidak dapat terlepas dari peran pembelajarannya. Penerapan pendekatan sistem pembelajaran berbasis kompetensi mengarah kepada pengelolaan pembelajaran secara individu dan dapat menempatkan peserta didik menjadi subyek yang harus merencanakan, menggali, menginterprestasi serta mengevaluasi hasil belajarnya sendiri. Sedangkan pengajar hanya sebagai fasilitator yang harus senantiasa siap melayani kebutuhan belajar bagi peserta didik. Oleh karena itu, pengajar dituntut mampu menciptakan situasi pembelajaran yang menyenangkan (enjoyable learning), mampu mendorong motivasi dan minat belajar peserta didik. Salah satu pembelajaran menyenangkan yang menjadi trend belakangan ini adalah pembelajaran berbantuan virtual laboratory. Virtual laboratory merupakan bentuk objek multimedia interaktif. Objek multimedia interaktif terdiri dari berbagai format heterogen yaitu teks, hiperteks, suara, gambar, animasi, video, serta grafik. Secara umum, virtual laboratory berbentuk seperti simulasi, dimaksudkan untuk mentransfer pengetahuan konseptual dan pengetahuan prosedural. Namun untuk mencapai tujuan tersebut, lembaga pendidikan dihadapkan pada berbagai permasalahan menyangkut diri peserta didik, pengajar maupun fasilitas lainnya. Permasalahan-permasalahan tersebut juga timbul pada pembelajaran mata pelajaran Fisika. Dari pengamatan pada proses pembelajaran tampak bahwa motivasi peserta didik dalam mengikuti pelajaran perlu mendapat banyak perhatian. Hal ini terlihat dari kurangnya antusiasme, kurangnya kesadaran dan kemauan kuat untuk bertanya, serta kurang mampu mengutarakan ide yang merupakan bentuk kreativitas sebagai upaya dalam memahami materi masih terbilang rendah. Hal tersebut disebabkan oleh rendahnya penguasaan konsep peserta didik.

Pemanfaatan laboratorium virtual dalam proses pembelajaran menjadikan proses pembelajaran tersebut lebih efektif dari segi waktu dan meningkatkan prestasi belajar siswa [7]. Penelitian Bajpai pada tahun 2013 yang berjudul "Developing Concepts in Physics Through Virtual Lab Experiment: An Effectiveness Study" menyimpulkan bahwa pembelajaran konsep efek fotolistrik melalui virtual laboratory lebih efektif dibandingkan dengan real lab [8]. Studi tersebut juga menunjukkan penggunaan virtual laboratory dalam pembelajaran fisika lebih baik dalam meningkatkan pemahaman konsep siswa dibanding pembelajaran melalui real lab.

Pada hakekatnya fisika merupakan proses dan produk tentang pengkajian kejadian gejala alam. Proses (process or methods) adalah kegiatan yang meliputi observasi, membuat hipotesis, merencanakan dan melaksanakan eksperimen, evaluasi data pengukuran, dan sebagainya. Produk (product) merupakan hasil dari proses yang berbentuk fakta, konsep, prinsip, teori, hukum, dan sebagainya [9].

Salah satu penyebab rendahnya hasil belajar peserta didik adalah model pembelajaran yang sering digunakan oleh guru saat ini. Proses pembelajaran selama ini masih terkesan hanya berpusat pada guru (teacher oriented) yang menganggap bahwa guru adalah satu-satunya sumber ilmu utama dan serba tahu [10]. Metode ceramah yang sering diterapkan oleh pengajar menjadi salah satu penyebab kurang optimalnya proses pembelajaran. Metode ceramah paling sering digunakan oleh pengajar karena dalam situasi apapun metode ini akan lebih cepat dan mudah dalam memberikan informasi kepada peserta didik. Akibatnya peserta didik hanya memperoleh pengetahuan secara teoritis dan pasif, sementara itu hanya guru yang bertindak aktif untuk memberikan informasi.

Sebagai pemecahan dari permasalahan di atas, solusi yang dapat diterapkan yaitu dengan memperbaiki proses pembelajaran. Ada pun salah satu model pembelajaran yang dapat diajukan yaitu model pembelajaran kontekstual REACT. Model pembelajaran ini bernaung di bawah paham pembelajaran konstruktivisme yang menekankan bahwa pengetahuan dibangun dalam pikiran pebelajar dan model pembelajaran ini menekankan kebermaknaan belajar. Trianto menyatakan bahwa pembelajaran konstekstual adalah suatu konsep belajar yang membantu guru mengaitkan antara materi yang diajarkannya dengan situasi dunia nyata peserta didik dan mendorong peserta didik untuk membuat hubungan antara pengetahuan yang dimilikinya dengan 
penerapan dalam kehidupan sehari-hari [11]. Pembelajaran yang benar-benar bersifat kontekstual akan terjadi apabila peserta didik (siswa) mampu memproses informasi baru atau pengetahuan yang sedemikian rupa sesuai dengan acuan pikiran peserta didik (memori, pengalaman, dan respon). Selain itu pembelajaran kontekstual cenderung mencari makna, mencari hubungan yang masuk akal, serta mencari kebergunaan antara konsep materi yang dipelajari dengan situasi kehidupan dunia nyata. Model pembelajaran kontekstual REACT memiliki lima komponen belajar yang penting meliputi (1) relating atau belajar dalam konteks mengaitkan, (2) experiencing atau belajar dalam konteks mengalami, (3) applying atau belajar dalam konteks menerapkan, (4) cooperating atau belajar dalam konteks kerja sama, dan (5) transferring atau belajar dalam konteks alih pengetahuan [12]. Model pembelajaran ini dipandang memiliki efektivitas yang besar dalam mengembangkan pemahaman konsep peserta didik dan melalui model pembelajaran ini peserta didik juga berkesempatan untuk mengembangkan dan melatih keterampilan proses sains secara optimal.

Hasil penelitian yang telah dilakukan oleh Wibowo, dkk. Pada tahun 2013 menunjukkan bahwa model pembelajaran kontekstual REACT memiliki kriteria yang layak untuk digunakan sebagai model pembelajaran di sekolah [13]. Hasil penelitian yang dilakukan oleh K. Slamet, dkk. yang menunjukkan bahwa terdapat perbedaan pemahaman konsep fisika dan keterampilan proses sains antara kelompok siswa yang belajar dengan REACT dengan kelompok siswa yang belajar dengan model pembelajaran konvensional [14]. Penelitian ini diharapkan agar dapat memperbaiki pendidikan di Indonesia.

Berdasarkan uraian permasalahan tersebut, dapat diidentifikasi beberapa masalah sebagai berikut:

1. Skor TIMSS bidang fisika Indonesia sangat rendah dan berada di bawah rata-rata internasional, hal tersebut disebabkan karena pembelajaran fisika di Indonesia kurang merangsang dan kurang dapat meningkatkan kemampuan tingkat tinggi.

2. Pembelajaran fisika belum dilaksanakan sesuai hakikatnya, hal ini ditandai dengan sering ditemuinya pembelajaran fisika yang hanya cenderung melatih peserta didik untuk mengerjakan soal hitungan matematis tanpa mengetahui bagaimana menerapkannya dalam kehidupan sehari-hari.

3. Pembelajaran fisika cenderung hanya menekankan pada aspek kognitif, sedangkan aspek lain (afektif dan proses) diabaikan.

4. Pembelajaran fisika kurang inovatif dalam upaya mengajak peserta didik untuk berpartisipasi aktif dalam pembelajaran dalam memperdalam konsep, pengetahuan, dan fakta sains.

5. Banyak pengajar yang belum mengetahui cara yang tepat untuk mengantarkan peserta didik ke dalam pembelajaran penguasaan konsep pembelajaran.

Dari identifikasi masalah di atas, telah diketahui berbagai masalah sehingga dalam penelitian ini perlu dibatasi agar permasalahan tidak terlalu luas dan keberhasilannya dapat diukur. Adapun batasan dalam penelitian ini yaitu perlu dikembangkannya perangkat pembelajaran fisika (yaitu dengan menggunakan model REACT berbantuan virtual laboratory) yang mampu meningkatkan kemampuan peserta didik dalam penguasaan konsep pada materi dinamika rotasi dan kesetimbangan benda tegar.

Berdasarkan permasalahan dan keunggulan model pembelajaran REACT dan metode laboratorium virtual yang telah diungkapkan sebelumnya, penulis berkeinginan untuk menganalisis model pembelajaran REACT berbantuan virtual laboratory, maka penulis mengajukan sebuah penelitian yang berjudul "Pengaruh Model Pembelajaran REACT Berbantuan Virtual Laboratory terhadap Pemahaman Konsep Peserta didik ada Materi Dinamika Rtasi dan Kesetimbangan Benda Tegar".

Berdasarkan uraian latar belakang permasalahan di atas, maka masalah pokok yang akan dicari pemecahannya melalui penelitian ini adalah "Apakah terdapat perbedaan pemahaman konsep antara kelompok peserta didik yang belajar mengunakan model pembelajaran REACT berbantuan virtual laboratory, peserta didik yang belajar menggunakan model pembelajaran REACT dan peserta didik yang belajar menggunakan model pembelajaran konvensional?"

\section{Metode Penelitian}

Metode yang digunakan dalam kajian ini menggunakan metode atau pendekatan kepustakaan (library research), Studi pustaka atau kepustakaan dapat diartikan sebagai serangkaian kegiatan yang berkenaan dengan metode pengumpulan data pustaka, membaca dan mencatat serta mengolah bahan penelitian ( Zed, 2003:3). Dalam penelitian studi pustaka setidaknya ada empat ciri utama yang penulis perlu perhatikan diantaranya : Pertama, bahwa penulis atau peneliti berhadapan langsung dengan teks (nash) atau data angka, bukan dengan pengetahuan langsung dari lapangan. Kedua, data pustaka bersifat "siap pakai" artinya peniliti tidak terjung 
langsung kelapangan karena peneliti berhadapan langsung dengan sumber data yang ada di perpustakaan. Ketiga, bahwa data pustaka umumnya adalah sumber sekunder, dalam arti bahwa peneliti memperoleh bahan atau data dari tangan kedua dan bukan data orisinil dari data pertama di lapangan. Keempat, bahwa kondisi data pustaka tidak dibatasi oleh runga dan waktu (Zed, 2003:4-5). Berdasarkan dengan hal tersebut diatas, maka pengumpulan data dalam penelitian dilakukan dengan menelaah dan/atau mengekplorasi beberapa Jurnal, buku, dan dokumen-dokumen (baik yang berbentuk cetak maupun elektronik) serta sumber-sumber data dan atau informasi lainnya yang dianggap relevan dengan penelitian atau kajian. Pustaka yang dikaji adalah jurnal hasil penelitian yang sudah ada. Jurnal yang digunakan untuk kajian pustaka pada jurnal ini adalah jurnal yang berkaitan dengan model pembelajaran REACT dan pembelajaran yang berbantuan laboratorium virtual.

\section{Hasil Penelitian dan Pembahasan}

Ref. [14] Pemahaman konsep fisika dan keterampilan proses sains antara kelompok siswa yang belajar dengan REACT dengan kelompok siswa yang belajar dengan model pembelajaran konvensional. Ref. [13] Hasil penelitian tersebut juga diperkuat dengan hasil penelitian yang telah dilakukan oleh Wibowo, dkk. menunjukkan bahwa model pembelajaran kontekstual REACT memiliki kriteria yang layak untuk digunakan sebagai model pembelajaran di sekolah.

Untuk mendukung pembelajaran agar mencapai tujuan dalam belajar secara maksimal, maka dibutuhkan sebuah media yang dapat menunjang hal tersebut. Media yang digunakan dalam penelitian ini adalah menggunakan virtual laboratory. Ref. [7] Tatli dan Ayas dalam penelitiannya yang berjudul "effect of a Virtual Chemistry laboratory on students" Schievement" menyimpulkan bahwa pengembangan dan pemanfaatan teknologi laboratorium virtual lebih efektif dalam meningkatkan prestasi belajar dan ketrampilan laboratorium siswa dibandingkan proses pembelajaran melalui real laboratory. Penelitian ini memanfaatkan media VCL (Virtual Chemistry Laboratory), media ini memfasilitasi siswa dalam proses pembelajaran. Hal positif yang dapat diambil dari penelitian ini adalah pemanfaatan media virtual laboratory dapat meningkatkan prestasi belajar dan lebih efektif dibanding pembelajaran real laboratory. Dalam penelitian in juga disampaikan beberapa kelebihan mengenai penggunaan virtual laboratory yang cenderung lebih mudah dipahami dan fleksibel dalam pelaksanaannya. Ref. [8] Dari hasil penelitian yang dilakukan oleh Bajpai melakukan penelitian yang berjudul "Developing Concept in Physics Through Virtual Lab Experiment: An Effectiveness Study". Berdasarkan tes pemahaman konsep fisika siswa, diperoleh kesimpulan bahwa pembelajaran yang memanfaatkan virtual lab lebih efektif dalam meningkatkan pemahaman konsep fisika siswa dibanding pembelajaran melalui real lab. Penelitian ini juga memberikan kejelasan mengenai pentingnya memanfaatkan media berbasis teknologi dalam pembelajaran terutama yang berkaitan dengan virtual laboratory. Hal tersebut didasarkan pada hasil yang dicapai pada penelitian ini. Pemanfaatan virtual laboratory memungkinkan siswa belajar lebih aktif dan lebih antusias karena visualisasi dari media ini ditampilkan dengan menarik. Ref. [15]Penelitian yang dilakukan Singh berjudul "Virtual Learning Environment for Next Generation in Electronics \& Telecommunications Courses" menyimpulkan bahwa pemanfaatan VLE (Virtual Learning Environment) memberikan hasil yang serupa dengan proses pembelajaran konvensional yang harus melakukan face to face. Sedangkan melalui VLE pembelajaran tidak terbatas ruang dan waktu. Analisa yang dilakukan oleh peneliti menunjukkan VLE dapat diterapkan untuk materi yang lebih rumit sekalipun, bahkanakan menghasilkan pemahaman siswa yang lebih baik kedepannya. Penelitian ini jelas menekankan bahwa pemanfaatan teknologi virtual memang untuk generasi kedepan yang tentunya memerlukan literasi sains dan teknologi [13]. Diperkuat dengan penelitian yang dilakukan oleh Bakar dalam penelitiannya yang berjudul " $A n$ Effective Virtual Laboratory Approach for Chemistry" kesimpulan dari penelitian ini ialah pemanfaatan virtual laboratory sangat dianjurkan karena ditemukan bahwa siswa yang belajar menggunakan virtual laboratory memiliki prestasi belajar yang lebih baik daripada siswa yang belajar memalui metode konvensional. Penelitian ini memberikan gambaran bagaimana pemanfaatan virtual laboratory secara efektif meningkatkan prestasi belajar siswa. hal ini kembali berkaitan dengan kertertarikan dan kelebihan yang dimiliki pembelajaran yang memanfaatkan media virtual laboratory. Pada era globalisasi seperti ini pemanfaatan teknologi dalam pembelajaran bukan merupakan hal yang tabu untuk dilaksanakan, melainkan merupakan sebuah solusi dan keharusan dalam upaya peningkatan prestasi belajar siswa [16]. 


\section{Kesimpulan}

Dari hasil kajian studi pustaka yang telah dilakukan dapat diambil kesimpulan bahwa model pembelajaran REACT dapat meningkatkan pemahaman konsep siswa. Dan virtual laboratory juga dapat menunjang atau bahkan meningkatkan pemahaman konsep siswa. Jadi, model pembelajaran REACT dengan berbantuan virtual laboratory akan meningkatkan pemahaman konsep pada materi kesetimbangan benda tegar. Bagi peneliti selanjutnya, hasil penelitian ini bisa digunakan sebagai bahan perbandingan dan referensi untuk penelitian, dan sebagai bahan pertimbangan untuk lebih memperdalam penelitian selanjutnya.

\section{Ucapan Terimakasih}

Penulis mengucapkan terima kasih kepada rekan-rekan Jurusan Pendidikan Fisika yang telah ikut serta membantu dengan meluangkan waktu, pikiran, dan perhatiannya guna memberikan masukan dan saran dalam penulisan ini.

\section{Kepustakaan}

[1] Suastra, I W. 2009. Pembelajaran sains terkini: Mendekatkan peserta didik dengan lingkungan alamiah dan sosial budaya. Singaraja: Universitas Pendidikan Ganesha.

[2] Kompas. 2012. Indeks Pendidikan untuk semua masih stagnan. Berita Kompas Online. Tersedia pada http://edukasi.kompas.com/read/2012/10/20/04385981/Indeks.Pendidikan.untuk.Semua.Masih.Stagnan. Diakses tanggal 1 Desember 2019.

[3] Kemendikbud. 2011a. Panduan Pembinaan Pendidikan Karakter melalui Pengembangan Budaya Sekolah di Sekolah Dasar. Jakarta: Direktorat Pembinaan Sekolah Dasar.

[4] Gonzales, P., Leslie, J., Stephen, R., David, K., \& Summer, B. 2009. Highlight from TIMSS 2007: Mathematics and science achievement of u.s. fourth- and eighth-grade students in an international context. Institute of Education Science.

[5] Mundilarto. (2002). Kapita Selekta Pendidikan Fisika. Yogyakarta: FMIPA UNY.

[6] Anderson, O. W. \& Krathwohl, D. R. 2001. A Taxonomy for Learning, Teaching, and Assessing: A Revision of Bloom's Taxonomy of Educational Objectives. New York: Longman.

[7] Tatli, Z. \& Ayas, A. 2013. Effect of virtual chemistry laboratory on students' achievement. Journal of Educational Technology and Society, 16(1): 159-170. Tersedia pada http: //www.ifets. info/journals/16_1/14.pdf. Diakses tanggal 4 Desember 2019.

[8] Bajpai, M. 2013. Developing conceps in physics through virtual lab experiment: An effectiveness study. An International Journal of Education Technology, 3(1): 43-50. Tersedia pada http://www. ndpublisher.i n/admin/issues/tlv3n1f.pdf. Diakses tanggal 8 November 2019.

[9] Sutarto. 2003. "Studi Implementasi Kebijakan Pendidikan IPA-Fisika SMU di Indonesia". Disertasi. Jakarta: Universitas Pendidikan Indonesia.

[10] Sari, N. F., \& Nasikh. 2009. Efektivitas penerapan pembelajaran berbasis masalah dan teknik peta konsep dalam meningkatkan proses dan hasil belajar mata pelajaran ekonomi peserta didik kelas X6 SMAN 2 malang semester genap tahun ajaran 2006-2007. JPE 2 (1).

[11] Trianto. 2007. Model-model pembelajaran inovatif berorientasi konstruktivistik. Jakarta: Prestasi Pustaka.

[12] Career, C. D. P. (2007). The REACT Strategy. Texas Collaborative for Teaching Excellence.Tersedia pada: http:// info@texascollaborative.org.

[13] Wibowo, dkk. 2013. Pengembangan bahan ajar fisika berbasis react pada pokok bahasan fluida untuk siswa sma kelas XI. Jurnal Universitas.

[14] K. Slamet, dkk. 2013. Pengaruh Model Pembelajaran Kontekstual React Terhadap Pemahaman Konsep Fisika Dan Keterampilan Proses Sains Siswa Kelas VIII Smp. Jurnal Universitas Pendidikan Ganesha.

[15] Singh, K. G. 2013. Virtual Learning environment for next generation in electronics \& telecommunications courses. International Journal of Technological Exploration and Learning (IJTEL), 2 (5): 1-5. Tersedia pada http://www.researchgate.net/publication/256442147_Virtual_Learning_environment_for_next_generation_in_elec tronics_telecommunications_course/file/72e7e52296c59e8426.pdf. Diakses tanggal 24 November 2019.

[16] Bakar, N., Zaman, H. B., Kamalrudin, M., Jusoff, K., \& Khamis, N. 2013. An effective virtual laboratory approach for chemistry. Australian Journal of Basic and Applied Sciences, 7(3): 78-74. Tersedia pada http://www.ajbasweb.com/ajbas/2013/special\%2 0issue/78-84.pdf. Diakses tanggal 5 Desember 2019. 